\title{
BIAS GENDER \\ DALAM BUKU PELAJARAN SKI \\ TINGKAT MADRASAH IBTIDAIYAH
}

\author{
Abdul Gani Jamora Nasution \\ Fakultas Ilmu Tarbiyah dan Keguruan UIN Sumatera Utara Medan \\ J1. Willem Iskandar Pasar V Medan Estate, Sumatera Utara, 20371 \\ e-mail: abdulganijamoranasution@gmail.com
}

\begin{abstract}
Gender Bias in History of Islamic Civilization (SKI) Course Materials at Madrasah Ibtidaiyah Level. This article examines the issue of gender bias in Islamic civilization history textbooks at Madrasah Ibtidaiyah level. Specifically, this article examines the extent to which gender bias is possible in SKI lessons for material sphere, images and rubrics. The data obtained through the study of the document, by analyzing textbooks and course materials used by teachers at the level of Madrasah Ibtidaiyah. This study found that SKI textbooks are still gender biased. Therefore, it is necessary to write textbooks for madrasah students by taking into account the principle of gender equality, so that gender bias issues are not preserved by Islamic educational institutions in Indonesia. The findings of this study may serve as a basis for the government, in particular the Ministry of Religious Affairs, in determining policies on textbooks for madrasah that should promote gender equality.
\end{abstract}

Keywords: gender bias, madrasa, History of Islamic Civilization 


\section{Pendahuluan}

Pembahasan relasi laki-laki dan perempuan tidak pernah berhenti di atas meja kerja akademik. Kegelisan serta keresahan memetakan peran masing-masing kian terasa. Ini tentu bisa diamini dengan keterlibatan para kaum intelektual sekaligus aktivis organik yang biasa dikenal dengan gerakan feminis. Memetakan ulang peran laki-laki dan perempuan merupakan paket sebuah keharusan yang tidak bisa ditawar-tawar lagi. Karena sadar, dengan perkembangan pendekatan kajian keilmuan (Islam) semakin terasa terintegrasi.

Idealnya gerakan yang digencarkan pemikir serta gerakan aktivis feminis dalam mensosialisasikan berbasis keseteraan laki-laki dan perempuan (gender). Selalu didapati berbagai tantangan yang dihadapi dan menemukan persoalan yang "pelik". Tantangan yang dihadapi tentu dengan pola pemahaman yang tertanam selama ini, bahwa laki-laki memainkan peran sepenuhnya di arena publik dan perempuan harus tunduk dan patuh kepada laki-laki. Legitimasi pun berkembang dan diambil sesuai dengan kebutuhan. Kemudian, dihadapi juga persoalan yang "pelik" terasa rumit bagi kaum feminis yang mengagendakan dalam pandangannya bahwa laki-laki dan perempuan adalah setara, yakni formulasi yang harmonis praktik relasi laki-laki dan perempuan (domestik dan publik) yang terjebak pada praktik politik belaka yang ujungnya ditemukan subordinasi dan peran ganda (doubel borden) terhadap perempuan. Terlepas dari kedua persoalan yang dihadapi, diyakini dengan ijtihad akademik bahwa relasi lakilaki dan perempuan punya kajian historis. Perjalanan panjang dunia, perkembangan peradaban, serta kecerdasan dan kecanggihan manusia pada masanya memainkan peran penting dalam mengisi persoalan ini. Dari pra sejarah, Mesir Kuno, India kuno, China kuno, serta Arab pra-Islam telah berbeda pasca Nabi Muhammad SAW. hadir untuk mengemban misi ajaran Tuhan. Dengan perjalanan 
panjang ini, tentu akan dibantu melihat kondisi secara obyektif dengan mengimplementasikan historisitas komprehensif.

Pemahamannya adalah sejarah relasi manusia saat itu akan terbuka lebar dengan tinjauan kritis terhadap ideologi, doktrin, serta kultur yang melekat pada manusia saat itu. Tepat kiranya, persoalan laki-laki dan perempuan bisa dipetakan dengan dua teori. Pertama, teori nature (alami), yang diasosiasikan segala pembawaan manusia, baik laki-laki misalnya, punya penis dan zakun. Sedangkan perempuan misalnya, memiliki payudara, hamil, haid. Teori kedua, nurture (adaptasi), yaitu teori yang menekankan sifat yang dilekatkan kepada seseorang orang, bisa terjadi kepada laki-laki dan perempuan. Penggunaannya bisa ditimbalbalikkan, misalnya cerdas dan hebat. Konotasi ini tentu melibatkan semua elemen masyarakat tertentu yang terus menurus diwariskan.

Kedua teori di atas, menyelesaikan konflik yang selama ini dugaan banyak orang terhadap bias jenis kelamin. Karena, jenis kelamin bukanlah menjadi persoalan prinsipil dalam menjalankan relasi gender. Melainkan menekankan pada kontribusi kualitas dan kuantitas jenis kelamin tersebut. Kehadiran gender inilah menghantarkan pembahaman bahwa laki-laki dan perempuan sama-sama berpotensi mengembangkan kreativitas, kecerdasan, serta pengabdiannya kepada Tuhan. Bergandengan tangan demi terselenggaranya keharmonisan yang sejati. Dalam pengertiannya menghilangkan diskriminasi, subordinasi, streotipeyang dirasakan laki-laki maupun perempuan. Di sinilah urgensi sosialisasi gender mulai usia dini manusia. Yang lebih urgen adalah baik perempuan dan laki-laki tidak dibatasi dengan tembok-tembok ketabuan dalam mengembangkan kualitasnya sebagai manusia.

Narasi di atas memberikan peluang besar terhadap pendidikan Islam untuk mengakomodir sosialisasi dan penguatan gender. ${ }^{1}$ Mengingat eksistensi pendidikan Islam baik secara filosofis 
maupun institusi memegang peran penting atau wadah mempercepat sosialisasi gender tersebut. Tetapi, berdasarkan studi awal terhadap buku teks di madrasah, ditemukan adanya persoalan bias gender. Ketidaksetaraan lelaki dan perempuan masih tercermin dalam buku-buku teks pembelajaran.

Fokus kajian artikel ini adalah bias gender dalam buku pelajaran SKI di Madrasah Ibtidaiyah. Secara khusus, artikel ini hendak menjawab tiga persoalan. Pertama, bagaimanakah bias gender dalam materi dalam buku teks pembelajaran SKI di tingkat MI? Kedua, bagaimanakah bias gender dalam gambar ilustrasi dalam dalam buku teks pembelajaran SKI di tingkat MI? Ketiga, bagaimana bentuk dan jenis bias gender dalam rubrik pada dalam buku teks pembelajaran SKI di tingkat MI? Kajian ini merupakan hasil penelitian kepustakaan. Kajian ini menelaah buku pelajaran SKI di tingkat MI sesuai dengan Keputusan Peraturan Menteri Agama No. 000912 tahun 2013 tentang Kurikulum Madrasah 2013 Mata Pelajaran Pendidikan Agama Islam dan Bahasa Arab, yaitu buku ajar yang diterbitkan oleh Tiga Serangkai dari tingkat kelas III sampai kelas VI. Data dianalisis dengan metode analisis isi (content analysis) dan analisis gender (gender analysis).

\section{Teori dan Diskursus Gender}

Memahami gender merupakan lokalitas atribut yang dilekatkan pada laki-laki dan perempuan yang dibentuk secara kultural. Gender membedakan sturuktur setiap kehidupan sosial manusia berdasarkan perbedaan jenis kelamin. Karena itu, gender bisa berubah dari waktu ke waktu, dari satu tempat ke tempat lain, bahkan dari satu kelas ke kelas lain Narasi ini tentu menghantarkan pada sebuah konsep analisis sosial yang terjadi pada suatu masyarakat. Lain halnya dengan sex, yang memetakan konsepsi jenis kelamin 
manusia dan struktur anatomi biologis yang bersifat kodrati. ${ }^{2}$ Bagi pemerhati relasi perempuan dan laki-laki, konsekuensi perbedaan jenis kelamin (sex) menjadikan sebuah kontruksi masyarakat untuk memetakan kehidupan sosial, yang pada akhirnya muncul urusan domestik untuk perempuan dan urusan publik untuk laki-laki. ${ }^{3}$

Dengan ungkapan yang berbeda, Caplan (1987) menyebut bahwa perbedaan antara laki-laki dan perempuan bukan sekadar biologis, namun secara sosial dan kultural. Terbentuknya perbedaanperbedaan gender disebabkan beberapa hal, di antaranya, dibentuk, disosialisasikan, diperkuat, bahkan dikonstruksi secara sosial dan kultural, melalui ajaran keagamaan maupun negara. Melalui proses panjang tersebut akhirnya dianggap kodrat. ${ }^{4}$ Sejarah mencatat bahwa hubungan antara laki-laki dan perempuan di berbagai belahan dunia, baik pra-Islam maupun masa Islam hingga sekarang, pihak laki-laki selalu berada dalam posisi dominan, walaupun kaum perempuan juga pernah mengukir sejarah dominasinya. Superioritas dan dominasi laki-laki dicontohkan dalam sejarah, misalnya terjadinya poligami yang melibatkan penguasaan di berbagai negara, seperti di Persia, Eropa, Asia Barat, Athena, Yunani, Romawi, bahkan negara Islam seperti Madinah dan masa kerajaan Islam di Indonesia. Superioritas kaum perempuan juga mempunyai bukti sejarah bahwa di masyarakat Arab praIslam pernah mengalami sistem keluarga matrilinial, di mana pertalian keluarga dicatat dari pihak perempuan. ${ }^{5}$

Dalam dunia Islam, debat masa kini tentang feminisme, gender dan hak-hak perempuan adalah beban secara ideologis, karena sudah tertanam dalam sejarah dari polemik peradaban antara Islam dan Barat. Diskursus gender dalam dunia Islam kontemporer digambarkan oleh sejarah sebagai konflik politik antara Islam dan Kristen dan juga kolonialisasi bangsa Barat terhadap dunia Muslim. ${ }^{6}$ Adapun istilah feminisme itu sendiri 
di dalam masyarakat pos-kolonial Arab Muslim dinodai dan tidak murni. Adapun, stereotip ini didasarkan pada permusuhan antara laki-laki dan wanita, dan juga imoralitas dalam bentuk persetubuhan seksual terhadap wanita. ${ }^{7}$

Perdebatan hubungan laki-laki dan perempuan yang umumnya dikenal dengan gender selama ini, khususnya di Indonesia, bukan hanya menyangkut realitas di lapangan, tetapi juga merembet pada perdebatan seputar pemahaman tentang pesan Tuhan yang terefleksikan dalam mushaf Utsmani. ${ }^{8}$ Dalam hal ini, pesan yang ada dalam mushaf 'Utsmani, secara bertahap dalam rentang waktu periodik sejarah yang panjang, ditafsirkan sehingga menghasilkan karya tafsir tradisional. Namun, menurut Amina, kebanyakan tafsir tradisional ditulis oleh laki-laki, berarti tafsir ini telah memasukkan pengalaman laki-laki di dalam penafsirannya. Sebaliknya pengalaman wanita ditiadakan atau justru malah ditafsirkan melalui visi laki-laki mulai dari perspektif, hasrat, dan kebutuhan tentang wanita. ${ }^{9}$ Sebab itu, menurut Amina, tidak ada metode penafsiran al-Qur'an yang benar-benar obyektif. Masing-masing penafsir akan membuat pilihan yang subyektif. ${ }^{10}$

Pemahaman dan penafsiran al-Qur'an yang subyektif jelas akan menutup pesan al-Qur'an yang sebenarnya obyektif. Pada saat al-Qur'an diturunkan, di tengah-tengah masyarakat Quraisy, budaya patriachal ${ }^{11}$ masih sangat kental, sehingga kebiasaankebiasaan usang tersebut masih melekat dan terdapat pada diri sementara ulama, yang pandangannya terkesan menyudutkan para perempuan. ${ }^{2}$ Padahal, menurut Arkoun, sebenarnya alQur'an itu memperbaiki status wanita, mengangkat derajat mereka menuju spiritualitas martabat yang sama sebagaimana seorang laki-laki. ${ }^{13}$ Wanita di dalam al-Qur'an juga diharapkan dapat menjalankan kewajiban agama sebagaimana yang dilakukan juga oleh laki-laki. ${ }^{14}$ Di sinilah betapa al-Qur'an (Islam) menjunjung tinggi wanita, sama seperti halnya laki-laki. Bahkan, ada juga 
pribahasa yang terkenal yaitu surga berada di bawah telapak kaki ibu. Hal ini menunjukkan, bahwa, Ibu memiliki tuntutan terlebih dahulu bahkan di atas ayah dalam soal kepatuhan dari seorang anak. ${ }^{15}$

Lebih konkrit, Khoiruddin Nasution memetakan sebab lahirnya konsep bias gender dalam Islam adalah sebagai akibat dari sepuluh faktor. Pertama, penggunaan studi Islam yang parsial. Kedua, belum ada kesadaran pentingnya perbedaan nash menjadi normatif universal dan praktis temporal. Ketiga, terkesan sejumlah nash memarginalkan wanita sebagai akibat penggunaan parsial. Keempat, budaya-budaya Muslim merasuk terhadap ajaran Islam. Kelima, dominasi teologi laki-laki dalam memahami nash. Keenam, kajian Islam dengan pendekatan agama murni. Ketujuh, generalisasi (mengambil hukum umum) dari kasus khusus. Kedelapan, mengambil hukum sebagai produk hukum dari penetapan hukum berdasarkan siyâsah al-syar'îah. Kesembilan, kajian Islam yang literalis dan a-historis (tekstual). Kesepuluh, peran kekuasaan (penguasa). ${ }^{16}$

\section{Keharusan Gender dalam Pendidikan}

Diskursus gender dalam pendidikan (Islam) bisa dirujuk pada karya Evi Muawwanah, bahwa ada tiga aspek permasalahan gender dalam pendidikan. Pertama, akses fasilitas pendidikan yang sulit dicapai. Kedua, partisipasi yang tercakup dalam bidang studi dan statistik pendidikan. Banyaknya perempuan mengambil bidang keguruan (SPG misalnya) karena pandangan yang mengatakan bahwa peran guru sebagai pembina juga pengasuh digambarkan sebagai kodrat perempuan sebagai ibu, oleh karenanya $99 \%$ SPG diminati perempuan, untuk STM sebanyak 99,5\% diminati laki-laki, guru TK sebagian besar juga perempuan. Hal ini dipengaruhi stereotipe gender. Ketiga, manfaat dan penguasaan (banyaknya buta huruf dialami oleh perempuan). 
Bias gender juga dapat dilihat dalam buku bacaan wajib di sekolah, yang sebagian besar mentransfer nilai atau norma gender yang berlaku dalam kebudayaan masyarakat. Artinya, sistem nilai gender akan berpengaruh pada kehidupan sistem sosial di sekolah. Sebagai contoh adalah buku ajar telah dikonstruksi peran gender perempuan dan laki-laki secara segregasi, ayah/ laki-laki digambarkan di kantor, di kebun dan sejenisnya (sektor publik), sementara perempuan atau ibu digambarkan di dapur, memasak, mencuci, mengasuh adik dan sejenisnya (domestik). ${ }^{17}$ Di samping itu, perilaku yang tampak dalam kehidupan sekolah interaksi guru-guru, guru-murid, dan murid-murid, baik di dalam maupun di luar kelas, pada saat pelajaran berlangsung maupun saat istirahat akan menampakkan konstruksi gender yang terbangun selama ini, yaitu bias. Siswa laki-laki selalu ditempatkan pada posisi menentukan, misalnya memimpin organisasi siswa, ketua kelas, diskusi kelompok, ataupun dalam pemberian kesempatan bertanya dan mengemukakan pendapat. Hal ini menunjukkan kesenjangan gender muncul dalam proses pembelajaran di sekolah terutama dipengaruhi oleh kurikulum dan buku-buku pelajaran yang belum berlandaskan pada peran gender yang seimbang terlebih para penulis sebagian besar laki-laki. ${ }^{18}$

Atas dasar persoalan tersebut, pendidikan khususnya pendidikan Islam perlu berbenah diri dengan menata ulang sistem relasi antara laki-laki dan perempuan, antara murid (laki-laki) dengan murid (perempuan), murid dengan gurunya dan lingkungannya untuk membangun sistem pendidikan yang tidak bias gender. Oleh karena pendidikan Islam bertanggung jawab terhadap produk anak didik yang dihasilkannya untuk berperan dan berkecimpung dalam kehidupan masyarakat yang lebih luas. Apabila sistem pendidikan yang di dalamnya terdapat praktik-praktik marginalisasi, maka bisa dilihat produk peserta didiknya semacam apa, dan begitu juga sebaliknya. Apabila sistem pendidikan yang di dalamnya 
terdapat praktik-praktik kesetaraan gender, produk peserta didiknya akan nampak seperti yang tercermin dari latar belakang pendidikannya dimulai dari cara berpikir (mindset) dan perilaku/tindakannya dalam menghadapi persolan relasi laki-laki dan perempuan dalam kehidupannya.

Dengan demikian, diperlukan adanya konsep pendidikan yang berbasis pada prinsip kesetaraan gender. Dalam rangka mengakomodir eskalasi gender, tentu membutuhkan peningkatan yang lebih baik. Peningkatan ini diarahkan pada manajemen pendidikan (Islam) dan pada proses pembelajaran. Pertama, manajemen responsif gender. Manajemen responsif gender ialah sebuah model manajemen yang menyediakan akses yang sama bagi laki-laki maupun perempuan untuk berperan di dalamnya serta menghasilkan manfaat yang sama bagi keduanya. Tujuan utama dari manajemen ini adalah mendorong terwujudnya prinsip keadilan antara laki-laki dan perempuan dalam menjalankan sistem manajemen pendidikan, yang meliputi fungsi pengembilan kebijakan, pelaksanaan kebijakan, serta evaluasi dan kontrol terhadap kebijakan di semua tingkatan. Selanjutnya, pemikiran dari manajemen responsif ini agar dapat dipastikan bahwa seluruh proses dalam manajemen pendidikan telah memperhatikan aspekaspek gender yang melekat di dalamnya. Bisa dicontohkan pada struktur organisasi, sistem kerja dan kebijakan-kebijakan yang ada.

Kedua, pembelajaran yang sensitif gender. Konstruksi bias gender yang melekat dalam budaya masyarakat turut mempengaruhi dalam proses pembelajaran. Pengutamaan (superioritas) lakilaki ditemukan, misalnya ketua kelas. Pembelajaran dengan dikhotomis akses, pemanfaatan fasilitas, dan kehawatiran terhadap jenis kelamin perempuan terus ditemukan. Perempuan yang selalu diasosiasikan pada yang lemah berkeliaran dalam proses pembelajaran. Ini tentu kontradiktif dengan amanah Undang-undang nomor 20 tahun 2003 tentang Sistem Pendidikan Nasional bab 1 pasal 
1 dan bab II pasal 3 juga mengisyaratkan bahwa dalam pendidikan peserta didik (tanpa dibedakan) dituntut secara aktif untuk mengembangkan potensi dirinya. Perlakuan yang sama antara laki-laki dan perempuan dalam memperoleh pendidikan yang bermutu jga ditegaskan dalam bab IV pasal 5. Untuk memastikan bahwa peserta didik mendapatkan hak yang sama untuk meningkatkan potensi dirinya, pada pasal 36 ayat 2 dan ayat 3 .

Ketiga, konsepsi pembelajaran inklusif gender. Pembelajaran inklusi gender adalah pembelajaran yang mempertimbangkan prinsip kesamaan akses, partisipasi, kontrol, dan manfaat. Memperhatikan aspek-aspek non-streotip, non-subordinasi, non-marjinalilasi, non beban kerja ganda, dan non-kekerasan pada kurikulum, rencana pembelajaran, dan manajemen kelas. Prinsip pembelajaran inklusif gender dapat dilihat dari kesamaan akses, kesempatan peserta didik dalam mendapatkan kurikulum dan kegiatan yang sama untuk semua mata pelajaran tanpa ada perbedaan.

Urgensi dari pembelajaran iklusif gender ini akan menjadikan peserta didik memperoleh akses pada sumber-sumber belajar, berpartisipasi dalam kegiatan pembelajaran, terlibat di dalam proses pengambilan keputusan di dalam pembelajaran dan mendapatkan manfaat dari hasil belajar. Begitu pula akan mencapai keadilan gender, peserta didik memperoleh perhatian yang sama terhadap kecenderungan dan kebutuhan yang berbeda (misalnya, kecenderungan belajar yang kompetitif dan kooperatif), sehingga dapat belajar secara aktif, kreatif, efektif dan menyenangkan. Hal lain yang tidak bisa diabaikan sebagai manfaat adalah peserta didik dapat berbagi pengalaman hidup yang berbeda-beda dengan nyaman dan leluasa, serta dapat berbagi pengalaman hidup yang dilalui mengikat mereka cenderung memiliki pengalaman yang berbeda. 


\section{Guru dan Diskriminasi Gender}

Peran guru sangat penting dan strategis pada semua fungsi pendidikan. Dalam rangka mempersiapkan anak menuju kehidupan yang demokratis, yang di dalamnya antara lain ditandai oleh nilai-nilai kehidupan yang egalitarian, peran guru sangat penting sebagai agen sosialisasi gender. Makin rendah jenjang pendidikan, makin penting peran ini, karena pada masa tersebut konstruksi nilai anak masih mudah dibentuk (dipengaruhi). Pada usia 8 tahun anak sangat rigid dalam memikirkan semua topik dan cenderung berlebihan dalam menggeneralisasikan fakta-fakta baru yang ditemukannya. ${ }^{19}$

Sosialisasi gender berawal di rumah dan terus berlanjut pada lingkup pergaulan yang lebih luas dan tingkat-tingkat pendidikan selanjutnya. Jenis informasi dan pengalaman belajar yang dialami anak berperan penting dalam sosialisasi gender, dan hal ini sangat diwarnai oleh gurunya. Pengalaman belajar yang diwarnai oleh konstruksi gender tradisional akan mengukuhkan kerangka gender tradisional yang mungkin telah dimiliki anak, karena masih banyak pengalaman sosialisasi di rumah yang diwarnai oleh konstruksi gender tradisional. Di lain pihak, pengalaman belajar yang diwarnai oleh konstruksi gender yang berbeda dengan konstruksi gender awal dari anak akan memberikan alternatif pengalaman kepada anak yang dapat memengaruhi bahkan mengubah konstruksi gender anak yang tradisional. Di sinilah peran penting pendidikan, sekolah, dan guru dalam sosialisasi gender.

Di sekolah, guru paling banyak menciptakan pengalaman belajar. Karena itu perlakuan guru, interaksi yang diciptakan guru, pernyataan, atau juga respons yang dilakukan guru merupakan sumber belajar bagi anak. Bagi banyak anak, guru adalah sebagai sumber informasi, model identifikasi, dan imitasi. ${ }^{20}$ Peran tersebut semakin penting karena buku teks yang dipergunakan di sekolah 
masih banyak yang bias gender. Buku-buku teks di sekolah melalui kalimat dan gambar-gambarnya masih sering bias gender dengan memberikan keutamaan kepada laki-laki (patriarkhi). Buku ajar, begitu juga kurikulum, yang belum berdasarkan peran gender seimbang ini akan dapat menyebabkan perempuan tetap tidak mempunyai mentalitas yang produktif. ${ }^{21}$ Informasi yang bias gender dalam jangka panjang memberikan dampak yang berbeda terhadap perkembangan anak laki-laki dan perempuan. Buku-buku teks yang dibaca dapat memengaruhi sikap dan opini anak. Kalimat-kalimat yang dibaca anak bisa berubah menjadi ideologi bila kelak ia dewasa. ${ }^{22}$ Semua ini terjadi karena di setiap buku selain tujuan kurikuler juga terkandung tujuan kurikuler tersembunyi (hidden curriculum) yang berupa nilainilai yang diharapkan tertanam pada diri siswa. Karena itu guru disarankan dapat memilih buku yang tidak bias gender atau paling tidak dapat memberikan respons yang positif terhadap materi bias gender dalam buku-buku yang terpaksa dipergunakan. ${ }^{23}$

\section{Bias Gender dalam Buku Pelajaran SKI}

Sampailah pada pembahasan kontruksi Sejarah Kebudayaan Islam (untuk selanjutnya disingkat SKI) tingkat Madrasah Ibtidaiyah (selanjutnya disingkat MI), sebagai fakta yang bisa disodorkan untuk didiskusikan lebih lanjut terhadap implementasi gender dalam pendidikan (Islam). Memilih SKI sebagai kajian tentu memiliki tantangan tersendiri dalam mengupas persoalan keseteraan gender. Mengingat, sejarah secara umum ternyata mengupas dominasi peran laki-laki ketimbang perempuan. Hingga perempuan sendiri pun ketika ditanya tentang tokoh yang diidolakannya hanya menjawab tokoh laki-laki. Lantas, bagaimana dengan fakta yang termuat dalam SKI? 


\section{Bias Gender dalam Materi Pelajaran SKI Tingkat Madrasah Ibtidaiyah}

Secara akumulasi persentase dari kelas III hingga kelas VI ketokohan dan atau peran yang diasosiasikan kepada salah satu jenis kelamin terlihat tidak ada ada keseimbangan. Lebih jelasnya lihat di bawah ini:

Grafik 1

Grafik Tokoh/peran dalam Materi

- Laki-laki " Perempuan

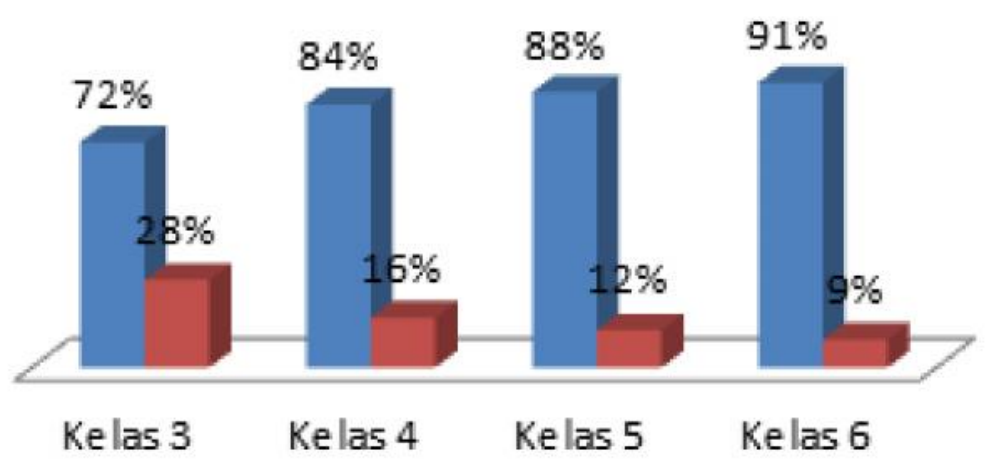

Kemudian, dalam narasi materi yang termasuk bias gender adalah:

\section{Buku Kelas III}

Pertama. Topik pelajaran kondisi sosial ekonomi masyarakat Arab pra-Isalam didapati sifat dan watak bangsa Arab pada sub pembahasan sifat dan watak tidak terpuji terjadi ketidakseimbangan dalam penulisan sejarah. Misal, penjelasan sifat dan watak tidak terpuji diperdapati violence dialami perempuan "dengan mengubur anak perempuan hidup-hidup" dan memperistri perempuan 
bekas istri ayah". Padahal, dua item lainnya (menyembah berhala, berpesta pora dan mabuk-mabukan) hanya dijelaskan secara netral, tidak ditemukan dalam kalimat penegasan atas nama jenis kelamin.

Kedua, pada topik pelajaran kerasulan Muhammad dengan sub pembahasan Nabi Muhammad SAW. berdakwah, dalam buku tersebut dijelaskan bahwa ada istilah al-sabiqûn al-awwalûn (orang-orang yang pertama kali masuk Islam) terjadi marginalisasi, yakni hanya dua orang perempuan yang disebutkan lainnya laki-laki.

\section{Buku Kelas Kelas IV}

Pertama, kasus penentangan Abu Lahab pada topik pelajaran yang kedua, yakni terjadi streotipe negatif terhadap laki-laki yang selalu menentang dakwah Nabi Muhammad SAW. Pada kasus tersebut Abu Lahab ditonjolkan namun tidak pernah digubris bagaimana peran Istri Abu Lahab. Padahal Q.S. alLahab secara jelas dimasukkan peran Istrinya.

Kedua, ditemukan pula pada topik pelajaran ketiga dengan penggunaan kata "muslim": "Sebagai seorang muslim, tidak ada teladan yang lebih baik kecuali Nabi Muhammad SAW. dalam kehidupan bermasyarakat, Nabi Muhammad SAW. memberikan contoh yang baik kepada kita semua". Kalimat "muslim" terjebak pada penggunaan kata bahasa Arab yang menunjukkan pada laki-laki dan sebagai antonimnya adalah muslimah.

Ketiga, narasi paragraf yang dibangun dalam topik pelajaran yang ketiga ini terdapat perilaku Nabi Muhammad SAW. memperlakukan perempuan urusan dapur dan pasar. Untuk lebih jelasnya lihat teks yang di bawah ini yang rentan dipahami bahwa urusan dapur dan pasar adalah urusan (kewajiban) perempuan: 
Pernah suatu ketika Nabi Muhammad SAW. pulang pagi hari. Beliau tidak menemukan sesuatu pun yang bisa dimakan. Yang mentah pun tida ada karena 'Ai'syah belum pergi ke pasar. Nabi Muhammad SAW. kemudian bertanya: belum ada sarapan, ya Humaira? Humaira adalah panggilan untuk 'Ai'syah. 'Ai'syah menjawab, belum ada apa-apa ya Rasulluah. Nabi Muhammad SAW. kemudian berkata, jika demikian aku puasa saja hari ini”.

\section{Buku Kelas Kelas V}

Kalkulasi data nama peran atau yang diasosiasikan pada salah satu jenis kelamin adalah sebagai berikut. Pertama, lakilaki 149 kali (88\%). Kedua, perempuan 21 kali (12\%) dari jumlah keseleruhan 170 kali penyebutan nama, peran atau tokoh. Sukar untuk menentukan bias gender dalam materi kelas lima ini dikarenakan ketokohan yang dimunculkan hanya laki-laki. Memang, topik pelajaran kelas lima ini didominasi peperangan-peperangan di masa Rasul. Jadi, kalkulasi data perempuan yang menempati $(12 \%)$ hanya didapati ketika topik pelajaran pembahasan akhir hayat Nabi Muhammad SAW. Namun, terasa tidak adil juga karena sejarah memberikan penjelasan peran perempuan berkenaan topik pelajaran pada kelas lima sangat berpariatif.

\section{Buku Kelas VI}

Pertama, pada kelas enam ini terasa atmosfir penyebarluasan bias gender bahwa perempuan hanya $18 \mathrm{kali}(12 \%)$ penyebutan nama perempuan dan bahkan berdasarkan penelusuran hanya sebagai nomor dua untuk penyebutan nama istri-istri sahabat Nabi (laki-laki) yang dinarasikan. Namun, secara aktif berperan hanya Aisyah, itu pun ketika perang saudara (perang jamal) antara pihak Ali dengan Aisyah dengan missi menindak lanjuti terbunuhnya khalifah Usman. 
Kedua, yang meresahkan adalah ketika pembahasan akhir dari pelajaran yakni tokoh-tokoh Islam Indonesia. Itu pun tidak termuat biografi perempuan. Padahal, banyak deretan nama perempuan Islam Indonesia yang berjuang untuk mengangkat harkat martabat bangsa Indonesia.

\section{Bias Gender dalam Gambar Pelajaran SKI Tingkat Madrasah Ibtidaiyah}

Urgensi gambar dalam buku pelajaran tingkat MI memiliki nilai plus dalam menstimulus akselerasi tercapai tujuan pembelajaran. Nilai plus yang dimaksudkan, mengingat usia anak tingkat MI dikategorikan masa anak-anak tengah yang notabene-nya skill dan penguasaan (kritik psiko-kognitif) memasuki tahap konkrit, pemahaman matematik dan lain sebagainya. Namun, dengan kondisi nyata yang diperdapatkan dalam buku pelajaran SKI MI masih diperdapati praktik bias gender. Lebih jelasnya disebutkan di bawah ini. Pertama, gambar permanen.

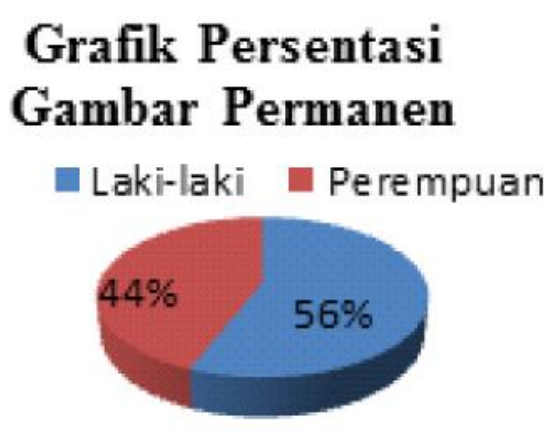

Maksud dari gambar permaen adalah gambar yang diperdapati pada setiap jenjang kelas. Guna akurasi data yang terjebak dalam bias gender, bisa diperhatikan sebagai berikut. Pertama, lakilaki. Dalam gambar tersebut tindakan laki-laki yaitu belajar, membaca, mendengarkan ceramah seorang guru atau kakek, 
dan bermain. Kedua, perempuan, yaitu belajar, membaca, mencium tangan seorang ibu atau guru.

Yang menarik di sini adalah bahwa dalam gambar belajar atau membaca baik laki-laki maupun perempuan perbedaanya pada belajar kelompok (group learning) hanya divisualisasikan pada perempuan. Bisa diambil kesimpulan, bahwa gambar ini memberikan nilai plus atau pelabelan positif terhadap perempuan. Karena, praktik sosial diperdapati dalam belajar kelompok. Kemudian, untuk laki-laki diasosiasikan pada "senang bermain" dan perempuan tidak ditemukan praktik seperti. Satu sisi, bermain dilekatkan sama laki-laki melihat fenomena yang di sekitar (kritik sosiogame). Di sisi lain, kondisi perempuan selalu dilekatkan dengan belajar dan taat pada ibu atau guru. Penulisan seperti itu, mengamini fenomena sosial yang sedang berkembang. Didapati kesesuaian dengan pandangan yang dilontarkan M. Agus Nuryatno ${ }^{24}$ terhadap kritik idealisme dan pragmatisme pendidikan dengan melontarkan pertanyaan, apakah pendidikan akan lebih mempengaruhi realitas sosial ataukah realitas sosial yang akan lebih banyak mempengaruhi pendidikan?

Kedua, gambar ilustrasi materi pelajaran.

\section{Grafik Gambar Ilustrasi Materi}

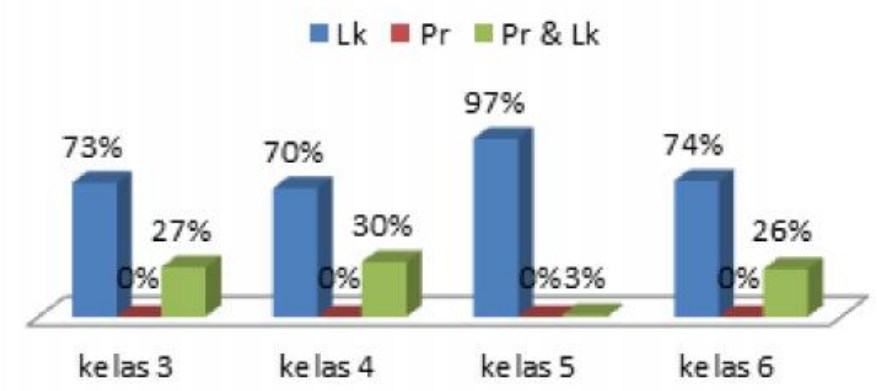

Grafik di atas ada tiga kolom pertama warna hijau untuk laki-laki, warna merah untuk perempuan, dan warna hijau. Setiap 
kelas ternyata tidak ditemukan mengilustrasikan untuk gambar dikhususnya untuk perempuan. Perempuan hanya didapati ketika bergabung dengan laki-laki. Sedangkan gambar laki-laki didapati menempati di atas 70\% hingga 97\%.

Ketiga, gambar qishshah mu'ashshirah

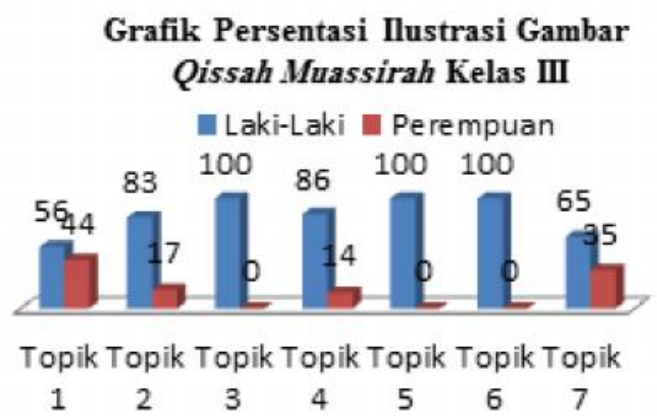

Grafik persentasi mulai dari kelas tiga hingga kelas enam menempatkan perempuan dalam mengilustrasikan gambar selalu dominasi laki-laki. Alasan yang paling tepat adalah dalam rubrik yang bergambar tersebut hanya dinarasikan untuk peran lakilaki. Sedangkan perempuan tidak pernah digubris perannya sama sekali. Kecuali hanya dua kali, seorang ibu dan seorang anak perempuan. Makanya, dalam mengilustrasikan gambar hanya mengikuti narasi yang ada. Sering kali, dalam topik pelajaran tidak diperdapati wajah perempuan.

\section{Bias Gender dalam Rubrik Pelajaran SKI Tingkat Madrasah Ibtidaiyah}

Rubrik pelajaran sesuai dengan macam klasifikasiya yaitu akhlâq mahmûdah, karakter bangsa, qirâ'ah mu'ashshirah dan qira'ah râsyidah. Untuk klasifikasi qira'áh râsyidah tidak didapati 
khusus kelas tiga. Oleh karenanya, memuat sesuai dengan item klasifikasi tersebut telah dijelaskan pada pembahasan sebelumnya.

Pada pembahasan akhlâq mahmûdah, karakter bangsa dan qirâ'ah mu'ashshirah. Masih banyak didapati bias gender dalam menjabarkan materi sebagai bentuk pengayaan. Baik yang terjebak dalam struktur pemakaian istilah bahasa ${ }^{25}$ maupun narasi yang hanya beriorentasi pada laki-laki. Sebagai penyegaran untuk mengingat dalam pembahasan sebelumnya, didapati kata "muslim", "siswa", "suami menyuruh istri untuk menyiapkan makan". Dalam karakter bangsa, kelas enam memuat topik pelajaran tentang khalifah yang diasosiasiakan jiwa kepemimpinan. Pembahasan tersebut rentan memiliki bias yang hampir dipahami khalifah dalam tataran normatif hanya untuk laki-laki bukan sebagai penggunaan struktur bahasa saja. Klaim kepemimpinan ketika tidak diulas secara komprehensif maka direkomendasikan untuk masa kini hanya pemimpin untuk laki-laki. Di sinilah urgensi nalar kritis yang seimbang melihat fenomena teks seperti penjelasan Nasruddin Umar. ${ }^{26}$

Dalam qirâah mu'ashshirah yang diperankan hanya lakilaki (Pak Guru, Ahmad, Hasan, Abu, Huma, Dodo, Amin, Pak Budi, Pak Harun, Jahil, Ilham, seorang pengemis, Amir, Ustaz Fadil). Sedangkan perempuan hanya dua kali dalam penyebutan mulai dari kelas tiga hingga kelas enam yaitu Ibu dan Zahra. Makanya, timbul guyonan dalam benak pikiran peneliti "janganjangan penulis buku SKI MI ini sudah tahu bahwa guru yang mengajar di SKI di Indonesia adalah perempuan? Sehingga tidak dibutuhkan lagi peran Ibu guru dalam rubrik. Atau "janganjangan penulis buku tahu betul hanya siswa laki-laki yang ada. Makanya, narasi diorientasikan untuk itibar bagi laki-laki.

Kemudian beranjak ke qirâ'ah mu'ashshirah dengan bahasa sederhana "biografi mini." Seperti diulas pada pembahasan sebelumnya merekomendasikan hanya satu kali diperdapati cerita teladan 
yang mengangkat tentang perempuan yakni Maimunah binti al-Haris. Nama aslinya adalah Barrah binti al-Haris. Ia juga termasuk istri Nabi yang beliau nikahi pasca umat Islam terbebas dari keterikatan pejanjian Hudaibiyah yang melarang untuk melaksanakan haji di Makkah, selebihnya hanya biografi laki-laki.

Tentu sangat menarik, jika membuka lembaran-lembaran sejarah akan peran perempuan sejarah Islam, berbagai anggapan berkeliaran bahwa perempuan masa Islam (masa Nabi dan masa sahabat) ditempatkan dalam rumah dan tidak bersentuhan dengan urususan publik. Ternyata, anggapan itu salah. Masa Nabi tentu tidak terelakkan dengan dinamika yang bergejolak dalam masyarakat Arab yang dikenal dengan perang. Perang, ternyata bukan hanya laki-laki saja yang berpartisipasi.

Melanjutkan tesis yang dikemukan Asghar Ali Engineer, ${ }^{27}$ sederatan nama menghiasi buku târîkh (sejarah) Islam yang tidak ternapikan partisipasi perempuan di kala itu. Misalnya, perang Uhud ikut serta di dalamnya istri Nabi. Satu orang menggambarkan bahwa ia melihat ' $A$ 'isyah dan istri Nabi yang lain membawa air untuk laki-laki di medan perang. Perempuan lain yang berada di kubu Islam disebutkan membawa pejuang yang terluka serta memindahkan yang mati dan terluka dari medan perang. Perempuan lain, misalnya Ummu Salim didapati membawa pisau. Ketika Nabi menanyakan mengapa ia membawa pisau tersebut, ia menjawab agar dapat merobek perut musuh, Nabi tersenyum kepadanya dan Rabi' binti Mu'adz. Rabi' binti Mu'adz membawa para syuhada dan yang terluka dari medan perang Uhud ke Madinah. Ummu Raqidah, memiliki pavilion untuk orang-orang yang terluka dimana ia mencuci dan membalut luka mereka dan Ummu Athiyah perempuan yang memasak untuk para prajurit di tujuh pertempuran.

Kemudian Asghar mengetengahkan kitab Fath Khaibar karya Abû Dâwûd, diperdapati narasi yang diriwayatkan Abû 


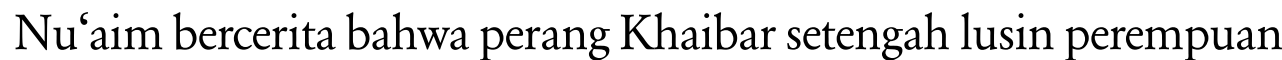
Madinah ikut tentara Islam. Nabi tidak mengetahui hal tersebut, dan ketika ia diberitahu, ia marah dan berkata: "mengapa mereka ikut? Perempuan ini menimpali bahwa mereka membawa obatobatan, dan mereka akan merawat, dan membalut tentara yang luka, mencabut panah dari tubuh tentara, mengatur makanan mereka. Mendengar ini, Nabi mengizinkan mereka untuk menemani tentara. Ketika Khaibar ditaklukkan ia juga membagi harta rampasan kepada para perempuan ini.

Perang Khandak, Syafi'ah (bibi Nabi) hadir dalam perang. Di sana banyak perempuan dan anak-anak dikepung oleh Bani Quraidzah berketepatan tidak ada tentara yang melindungi mereka. Kemudian Syafi'ah meminta Hassan bin Tsabit untuk membunuh tentara bani Quraidzah namun, Hassan ragu-ragu. Lalu Syafi'ah keluar dari benteng dan mengambil sebuah galah dari tenda dan membunuh tentara kafir tersebut.

Ummu Ammarah, perempuan yang tetap dalam peperang Uhud, ketika banyak sahabat laki-laki melarikan diri, ia melindungi Nabi dengan sebuah pedang. Pada hari itu, ia banyak menderita luka-luka di rangan dan di pundak. Ia juga hadir dalam perang melawan Nabi palsu "Musailamah" selama kekuasaan khalifah pertama, Abu Bakar. Ia terluka cukup serius dalam perang ini dan menderita dua belas luka.

Kemudian, masa penaklukan Syria, sederatan nama secara khusus oleh Balâdzurî dalam kitabnya Futuh al-Buldan, Ummu Hakim, Ummu Ammarah, Khaula, Lubna, dan Afira. Ummu Hakim diceritakan bahwa ia membunuh tujuh tentara Romawi sendirian dengan galah dari tendanya di dekat sebuah jembatan yang sekarang dikenal dengan jembatan Ummu Hakim dekat Damaskus. Perang Shiffin masa khalifah 'Ali bin Abi Thalib seperti Zarqa' dan Ummu Khair, berpartisipasi dalam perang. Bukan hanya itu, mereka memberikan inspirasi kepada para 
tentara dengan pidato mereka yang berapi-api. M. Quraish Shihab ${ }^{28}$ dalam salah satu makalahnya, menyebutkan peran partisipatif perempuan masa awal Islam dengan merujuk pada ahli hadis Imam Bukhârî, ditemukan secara khusus membukukan babbab dalam kitab Shahîh-nya tentang kegiatan kaum perempuan seperti "bab keterlibatan perempuan dalam Jihad, bab peperangan perempuan di lautan, atau bab keterlibatan perempuan merawat korban”.

Masih pejelasan Shihab, deretan nama perempuan dikenal dengan profesinya misalnya, perias pengantin (Ummu Salim binti Malhan), bidang perdagangan selain Khadijah binti Khuwailid ada Qailah Ummu Nabi Anmar yang datang kepada Nabi meminta petunjuk-petunjuk bidang jual beli. Raitah, istri Abdullah bin Ma'ud sangat aktif bekerja karena suami dan anaknya ketika itu tidak mampu mencukupi kebutuhan hidup keluarga. AsySyifâ', seorang perempuan yang pandai menulis ditugaskan oleh khalifah 'Umar bin Khaththâb sebagai petugas yang menangani pasar kota Madinah. Urusan sosial politik terkenal Ummu Hani’ ketika memberi jaminan keamanan sementara kepada orang musyrik. $^{29}$

Khusus untuk pembahasan tokoh-tokoh Islam di Indonesia, satu pun tidak didapati pembahasan tokoh perempuan. Padahal seperti dijelaskan pada bab II banyak deretan nama perempuan sesuai dengan bidang masing-masing baik bergerak secara individu maupun bergerak secara lembaga atau organisasi.

\section{Penutup}

Berdasarkan pembahasan di atas, dapat ditarik tiga kesimpulan. Pertama, bias gender dalam materi pelajaran SKI masih terdapat penyebarluasan bias gender berupa marginalisasi, subordinasi, dan streotipe terlihat ketika pembahasan ketokohan atau peran 
sejarah, juga terdapat bahasa yang digunakan menguntungkan pada pihak laki-laki, didukung data persentasi rata-rata akumulasi kelas (laki-laki sebesar 83.75\% dan perempuan 19.25\%).

Kedua, bias gender dalam gambar. Gambar dalam buku pelajaran berupa gambar permanen, gambar ilustrasi pelajaran, dan gambar qishshah mu'ashshirah menampilkan wajah dan perilaku yang didominasi laki-laki daripada perempuan merujuk pada manifestasi bias gender. Didukung data persentasi frekuensi wajah peran atau tokoh yang ditampilkan. (a) gambar permanen laki-laki 56\% dan perempuan 44\%. (b) gambar ilustrasi pelajaran, dengan rata-rata akumulasi laki-laki $78.5 \%$ dan perempuan $21.5 \%$ (c) gambar qishshah mu'ashshirah frekuensi secara rata-rata akumulusi laki-laki $83.70 \%$ dan perempuan 17.54\%.

Ketiga, bias gender dalam rubrik dengan jenis rubrik akhlak terpuji, karakter bangsa, qirâ‘ah mu'ashshirah, dan qirấah râsyidah, masih diperdapati penggunaan bahasa yang memarginalkan, mensubordinasi, dan stretiope terhadap salah satu jenis kelamin. Bahkan dalam qirâ‘ah râsyidah sebanyak 18 kali hanya satu kali biografi perempuan yang dijabarkan. Sebagai kontribusi penelitian ini dengan menyadari bahwa SK-KD dari Kementerian Agama. Karenanya, para penerbit buku dan atau penulis buku harus lebih memperhatikan isu-isu gender dalam implementasi buku pelajaran SKI tingkat MI.

\section{Pustaka Acuan}

Ahmed, Leila. Women and Gender in Islam \& Historical Roots of a Modern Debate. New Haven \& London: Yale University Press, 1992.

Arkoun, Mohammed. Rethinking Islam: Common Question, Uncommon Answer. Oxford: Westview Press, 1994. 
Bennett, Linda Rae. "Zina and the Enigma of Sex Education for Indonesian Muslim Youth,” dalam Sex Education, Vol. 7, Issue 4, 2007.

Bryan, et al. "Sex-Role Learning: A Test of Selective Attention Hypothesis", dalam Child Development, Vol. 49, Maret 1978.

Engineer, Asghar Ali. Pembebasan Perempuan, terj. Agus Nuryatno. Yogyakarta: 2007.

Jerome, Kagan \& Cynthia Lang. Psychology and Education: An Introduction. New York: Harcourt Brace Javanovich, Inc, 1984.

Kandiyoti, Deniz. "Islam and Patriarchy: A Comparative Perspective," dalam Nikki R. Keddie \& Beth Baron (ed.). Women in Middle Eastern History: Shifting Boundaries in Sex and Gender. New Haven \& London: Yale University, 1991.

Kull, Ann. "At the Forefront of a Post-Patriachal Islamic Education: Female Teachers in Indonesia," dalam Journal of International Women's Studies, Vol. 11, Isuue 1, 2009.

Lau, Annie. "Gender, Power and Relationships Ethno-Cultural And Religious Issues," dalam Charlotte Burck Speed \& And Bebe (ed.). Gender, Power, And Relationship. London; Routledge, 1995.

Muawanah, Elfi. Pendidikan Gender dan Hak Asasi Manusia. Yogyakarta: Teras, 2009.

Murniati. "Perempuan Indonesia dan Pola Ketergantungan," dalam Budi Susanto, et al. (ed.). Citra Wanita dan Kekuasaannya, Seri Siasat Kebudayaan. Yogyakarta: Kanisius, 1992.

Muthali'in, Achmad. Bias Jender dalam Pendidikan. Surakarta: Muhammadiyah University Press, 2001.

Nasution, Khoiruddin. Pengantar Studi Islam. Yogyakarta: AcademiaTazzafa, 2009. 
Nuryatno, M. Agus. "Urgensi Filsafat Pendidikan dalam Pusaran Pragmatisme," dalam Mukhrizal Arif, et al., Pendidikan Pos-Modernisme: Telaah Pemikiran Tokoh Pendidikan. Yogyakarta: Ar-Ruz Media, 2014.

Oey-Gardiner, Mayling. "Gender Differences in Schooling in Indonesia," dalam Bulletin of Indonesian Economic Studies, Vol. 27, Issue 1, 1991.

Rodiah, et al., Studi al-Quran: Metode \& Konsep. Yogyakarta: Elsaq Press, 2010.

Schimmel, Annemarie. My Soul is a Woman: The Feminine in Islam. New York: Continum, 1997.

Shihab, M. Quraish. “Konsep Wanita menurut Qur'an, Hadis, dan Sumber-sumber Ajaran Islam,” dalam Leis M. MarcoesNatsir \& Johan Meuleman (ed.). Wanita Islam Indonesia dalam Kajian tekstual dan Kontekstual: Kumpulan Makalah Seminar. Jakarta: INIS, 1993.

Srimulyani, Eka. "Muslim Women and Education in Indonesia: The pondok pesantren experience," dalam Asia Pacific Journal of Education, Vol. 27, Issue 1, 2007.

Suryadi, Ace \& Cecep Idris. Kesetaraan Jender dalam Bidang Pendidikan. Bandung: Genesindo, 2004.

Syaikh, Sa'diyya. "Transforming Feminisms: Islam, Women and Gender Justice,” dalam Omid Shafi. Progressive Muslim on Justice, Gender and Pluralism. Oxford: One World, 2005.

Umar, Nasruddin. "Metode Penelitian Bersfektif Gender tentang Literatur Islam,” dalam Siti Ruhaini Dzuhaytin, et al. Rekonstruksi Metodologis Wacana Kesetaraan Gender dalam Islam. Yogyakarta: PSW UIN Sunan Kalijaga dan Pustaka Pelajar, 2002.

Wadud, Amina. Qur'an and Woman: Rereading the Sacred Text from a Woman's Perspective. New York: Oxford University Press, 1999. 
VOL. 1 NO. 2 JULI-DESEMBER 2017

Wijaya, Aksin. Menggugat Otentisitas Wahyu Tuhan: Kritik Atas Nalar Tafsir Gender. Yogyakarta: Safiria Insania Press, 2004. 


\section{Catatan Akhir:}

${ }^{1}$ Kajian gender dalam dunia pesantren, khususnya pesantren, bisa dibaca dalam Eka Srimulyani, "Muslim Women and Education in Indonesia: The pondok pesantren experience," dalam Asia Pacific Journal of Education, Vol. 27, Issue 1, 2007; Mayling Oey-Gardiner, "Gender Differences in Schooling in Indonesia," dalam Bulletin of Indonesian Economic Studies, Vol. 27, Issue 1, 1991; Linda Rae Bennett, "Zina and the Enigma of Sex Education for Indonesian Muslim Youth,” dalam Sex Education, Vol. 7, Issue 4, 2007; Ann Kull, "At the Forefront of a Post-Patriachal Islamic Education: Female Teachers in Indonesia," dalam Journal of International Women's Studies, Vol. 11, Isuue 1, 2009. Inggris).

${ }^{2}$ Yang pertama kali membedakan gender dengan sex adalah Ann Oakley (sosiolog

${ }^{3}$ Secara garis besar teori-teori gender ini dapat diklasifikasikan pada dua clauster. Pertama, teori nature yang mengatakan bahwa perbedaan peran laki-laki dengan perempuan ditentukan oleh faktor biologis. Kedua teori nurture, yang melihat bahwa poerbedaan karakter dan peran sosial antara laki-laki dan perempuan lebih ditentukan oleh faktor sosial budaya.perspektif ini menyimpulakn bahwa pembaguan kerja antara laki-laki dan perempuan dikonstruksikan opleh budaya, yakni relasi kuasa yang secara turun temurun dipertahankan.

${ }^{4}$ Khoiruddin Nasution, Pengantar Studi Islam (Yogyakarta: Academia-Tazzafa, 2009), h. 219.

${ }^{5}$ Aksin Wijaya, Menggugat Otentisitas Wahyu Tuhan; Kritik Atas Nalar Tafsir Gender (Yogyakarta: Safiria Insania Press, 2004), h. 134.

'Sa'diyya Syaikh, "Transforming Feminisms: Islam, Women and Gender Justice," dalam Omid Shafi, Progressive Muslim on Justice, Gender and Pluralism (Oxford: One World, 2005), h. 148. Di dalam periode modern ini, dalam momen yang krusial, akhirnya kembali mengartikulasikan dan mengelaborasi terhadap isu-isu wanita dan gender dalam masyarakat Muslim Arab yang terjadi di bawah pengaruh kolonialisme dalam gejolak sosio-politik, dan bertahan sampai saat ini. Lihat, Leila Ahmed, Women and Gender in Islam \& Historical Roots of a Modern Debate (New Haven \& London; Yale University Press, 1992), h. 3.

${ }^{7}$ Ibid., h. 149.

${ }^{8}$ Aksin Wijaya, Menggugat Otentisitas, h. 150.

'Amina Wadud, Qur'an and Woman: Rereading the Sacred Text from a Woman's Perspective (New York: Oxford University Press, 1999), h. 1-2.

${ }^{10}$ Ibid., h. 1.

${ }^{11}$ Bahkan, dalam sistem keluarga yang menganut sistem pratiarchal ada yang menganggapnya sebagai yang tetap dan abadi, karena patriarki dianggap sebagai sebuah ideologi. lihat, Deniz Kandiyoti, "Islam and Patriarchy: A Comparative Perspective," dalam Nikki R. Keddie dan Beth Baron (ed.), Women in Middle Eastern History: Shifting Boundaries in Sex and Gender (New Haven \& London: Yale University, 1991), h. 24 
${ }^{12}$ Rodiah, et al., Studi al-Quran; Metode \& Konsep (Yogyakarta: Elsaq Press, 2010), h. 146.

${ }^{13}$ Mohammed Arkoun, Rethinking Islam: Common Question, Uncommon Answer (Oxford: Westview Press, 1994), h. 60.

${ }^{14}$ Annemarie Schimmel, My Soul is a Woman: The Feminine in Islam (New York: Continum, 1997), h. 54.

${ }^{15}$ Annie Lau, "Gender, Power And Relationships Ethno-Cultural And Religious Issues," dalam Charlotte Burck And Bebe Speed (ed.), Gender, Power, And Relationship (London: Routledge, 1995), h. 123.

${ }^{16}$ Nasution, Pengantar Studi Islam., h. 240.

${ }^{17}$ Elfi Muawanah, Pendidikan Gender dan Hak Asasi Manusia (Yogyakarta: Teras, 2009), h. 54.

${ }^{18}$ Ibid., h. 55.

${ }^{19}$ Bryan, Janice Westlund dan Zella Luria, "Sex-Role Learning: A Test of Selective Attention Hypothesis," dalam Child Development, Vol. 49, Maret 1978 (1), 1978, h. 14. Anak-anak juga memegang kepercayaan mengenai peran-peran gender dengan sangat rigid. Dalam proses itu persetujuan guru pun merupakan cara yang paling efektif untuk mensosialisasikan peran gender pada anak. Dalam rangka sosialisasi nilai gender, guru merupakan sumber belajar dan model bagi anak dalam berimitasi dan identifikasi diri. Sikap dan perilaku gender guru sangat penting dalam memengaruhi dan mendekonstruksi gender anak. Lihat Kagan, Jerome, dan Cynthia Lang, Psychology and Education: An Introduction (New York: Harcourt Brace Javanovich, 1984), h. 62.

${ }^{20}$ Ibid., h. 64.

${ }^{21}$ Ace Suryadi dan Cecep Idris, Kesetaraan Jender dalam Bidang Pendidikan (Bandung: Genesindo, 2004), h. 163.

${ }^{22}$ Murniati, "Perempuan Indonesia dan Pola Ketergantungan," dalam Budi Susanto, et al. (ed.), Citra Wanita dan Kekuasaannya: Seri Siasat Kebudayaan (Yogyakarta: Kanisius, 1992), h. 28.

${ }^{23}$ Guru dan perangkat pendidikan di sekolah masih diwarnai oleh nilai gender tradisional. Akibatnya, pengalaman belajar yang diciptakannya pun cenderung mengukuhkan nilai-nilai gender tradisional yang telah lebih dahulu disosialisasikan kepada anak. Sensitivitas dan kesadaran gender serta respon guru terhadap hidden curriculum yang bias gender pun tidak terjadi. Akibatnya, sosialisasi gender yang terjadi di sekolah hampir selalu merupakan pengukuhan nilai gender tradisional. Kurikulum yang digunakan oleh pendidik terbagi menjadi dua. Pertama, bersifat overt curriculum, di mana dalam kurikulum ini semua unsur yang ada bersifat terbuka, dapat tergambar mulai dari tujuan pembelajaran, materi, dan topik-topik perkuliahan, bahan bacaan strategi pembelajaran dan evaluasi. Kedua, bersifat hidden curriculum, dimana kurikulum yang disampaikan oleh guru di kelas dengan menggunakan strategi pembelajaran dan media yang dipakai termasuk bahasa komunikasi yang digunakan. Kurikulum sesungguhnya tidak hanya menggambarkan dan mencerminkan sikap dan pandangan yang ada di kelas dan lembaga pendidikan, tetapi juga menggambarkan masyarakat 
dan bahkan negara mengenai isu-isu tertentu, termasuk isu gender. Achmad Muthali'in, Bias Jender dalam Pendidikan (Surakarta: Muhammadiyah University Press, 2001), h. 95.

${ }^{24}$ M. Agus Nuryatno, "Urgensi Filsafat Pendidikan dalam Pusaran Pragmatisme," dalam Mukhrizal Arif, et al., Pendidikan Pos-Modernisme: Telaah Pemikiran Tokoh Pendidikan (Yogyakarta: Ar-Ruz Media, 2014), h. 11-12.

${ }^{25}$ Pemakaian bahasa seperti pemahasan sebelumnya yaitu, kata Muslim dan siswa. Penggunaan sturukutur bahasa pada domain kata ganti, diperdapai terjebak bias gender yang secera keseluruhan hanya diuntungkan kepada pihak laki-laki oleh Nasruddin Umar pembahasan pada bias dalam kata ganti (dhamir). Nasruddin Umar menyebutkan bias gender dalam penafsiran teks dalam kajian tradisi Islam yang dapat ditelusuri dalam sepuluh macam. Pertama, pembakuan tanda huruf, tanda bacam dan qirâ’at. Kedua, pengertian kosa kata (mufradat). Ketiga, menetapkan rujukan kata ganti (dhamir).Keempat, menetapkan batas pengecualian. Kelima, menetapkan arti huruf-huruf 'athf. Keenam, bias dalam struktur bahasa Arab. Ketujuh, bias dalam kamus bahasa Arab. Kedelapan, bias dalam metode tafsir. Kesembilan, bias dalam pembukuan dan pembakuan kitab-kitab fiqh. Kesepuluh, bias dalam kodifikasi kitabkitab hadis. Sebelas, bias riwayat-riwayat isrầiliyyat. Dua belas, bias berbagai mitos. Baca, Nasruddin Umar, "Metode Penelitian Perspektif Gender tentang Literatur Islam,” dalam Siti Ruhaini Dzuhaytin, et al., Rekonstruksi Metodologis Wacana Kesetaraan Gender dalam Islam (Yogyakarta: PSW UIN Sunan Kalijaga dan Pustaka Pelajar, 2002), h. 90-102.

${ }^{26}$ Nasruddin Umar mengatakan, bahwa kata khalifah dalam kamus Lisân al'Arab hanya diperuntukkan untuk laki-laki (al-khalîfatu la yakûnu illa al-zdukur). Ibid., h. 97.

${ }^{27}$ Asghar Ali Engineer, Pembebasan Perempuan, terj. Agus Nuryatno, cet. 2 (Yogyakarta: LKiS, 2007), h. 265-279.

${ }^{28} \mathrm{M}$. Quraish Shihab, “Konsep Wanita menurut Qur'an, Hadis, dan Sumbersumber Ajaran Islam,” dalam Leis M. Marcoes-Natsir dan Johan Meuleman (ed.), Wanita Islam Indonesia dalam Kajian tekstual dan Kontekstual: Kumpulan Makalah Seminar (Jakarta: INIS, 1993), h. 10.

${ }^{29}$ Ibid., h. 10-15. 
VOL. 1 NO. 2 JULI-DESEMBER 2017

\section{BIODATA PENULIS}

Ramli Abdul Wahid, dosen Pascasarjana UIN Sumatera Utara, Medan. Meraih gelar Master of Arts dan Doktor dalam bidang Hadis dari Program Pascasarjana IAIN Syarif Hidayatullah, Jakarta.

Agustiansyah, dosen Sekolah Tinggi Ilmu Tarbiyah Babussalam, Aceh Tenggara. Meraih gelar Magister of Arts dalam bidang Hukum Islam dari Program Pascasarjana UIN Sunan Kalijaga, Yogyakarta.

Irwansyah, dosen Fakultas Ilmu Sosial UIN Sumatera Utara, Medan. Meraih gelar Magister Agama dan Doktor dalam bidang Agama dan Filsafat Islam dari Pascasarjana IAIN Sumatera Utara, Medan.

Rafika Nisa dosen Sekolah Tinggi Ilmu Tarbiyah ar-Raudhah, Deli Serdang. Meraih gelar Master of Arts dalam bidang Pendidikan Islam dari Program Pascasarjana IAIN Sumatera Utara, Medan.

Abdul Gani Jamora Nasution, dosen Fakultas Ilmu Tarbiyah dan Keguruan UIN Sumatera Utara, Medan. Meraih gelar Master of Arts dalam bidang Pendidikan Guru Madrasah Ibtidaiyah dari Program Pascasarjana UIN Sunan Kalijaga, Yogyakarta. 


\section{UCAPAN TERIMA KASIH}

Dewan Redaksi menyampaikan terima kasih dan apresiasi kepada mitra bestari/penyunting ahli dalam proses penerbitan Journal of Contemporary Islam and Muslim Societies, Vol. 1 No. 2 JuliDesember 2017 atas kontribusi mereka dalam me-review dan mengomentari artikel-artikel dalam edisi ini. Mereka adalah:

1. Prof. Dr. Hasan Asari, MA (Universitas Islam Negeri Sumatera Utara, Medan).

2. Prof. Dr. Amroeni Drajat, M.Ag. (Universitas Islam Negeri Sumatera Utara, Medan).

3. Prof. Dr. Al Rasyidin, M.Ag. (Universitas Islam Negeri Sumatera Utara, Medan).

4. Dr. Mhd. Syahnan, MA (Universitas Islam Negeri Sumatera Utara, Medan). 
VOL. 1 NO. 2 JULI-DESEMBER 2017

\section{AUTHOR GUIDELINES}

The following guidelines for prospective authors apply:

1. Each manuscript should begin with a 180 -word abstract of its content.

2. Articles should be approximately 6000 words long; however, both shorter and longer manuscripts will be considered.

3. Articles could be based on either conceptual or empirical research findings.

4. Manuscripts should be submitted for consideration by email attachment; Microsoft Word is preferred.

5. Notes should be numbered in the form of endnotes.

6. Unless otherwise indicated earlier, abbreviations should be avoided. Titles of journals should be written out in full.

7. All article manuscripts will be peer-reviewed by qualified academics in the field; this is a process that may take weeks or months.

8. Manuscripts may be edited for style prior to publication.

9. Authors should be willing to respond to questions from readers of their articles.

10. The reference follows this format:

a. the Holy Qur'an

•. Q.S. Âli 'Imrân/3: 24.

- Abdullah Yusuf Ali, The Holy Qur'an: Translation and Commentary

(Lahore: Islamic Propagation Centre, 1946), p. 442. 


\section{b. Books}

- George Makdisi, The Rise of Colleges: Institutions of Learning in Islam and the West (Edinburgh: Edinburgh University Press, 1981), p. 312.

- Tobroni dan Syamsul Arifin, Islam: Pluralisme Budaya dan Politik (Yogyakarta: Sipress, 1994), p. 45.

- Slamet Effendi Yusuf, et al., Dinamika Kaum Santri: Menelusuri Jejak dan Pergolakan Internal NU (Jakarta: Rajawali, 1983), p. 23.

- Harun Nasution, Falsafat dan Mistisisme dalam Islam, second edition (Jakarta: Bulan Bintang, 1995), p. 21.

- Annemarie Schimmel, Jiwaku Adalah Wanita: Aspek Feminin dalam Spiritualitas Islam, translate Rahmani Astuti (Bandung: Mizan, 1998), p. 33.

- Syams al-Din Ahmad ibn Khallikan, Wafayât al-A 'yân waAnbâ' Abnâ' alamân, ed. Ihsan 'Abbâs (Beirut: Dâr al-Shâdir, 1977), volume IV, p. 551.

- Abû Hamîd al-Ghazâlî, al-Imlâ' fî Isykâlât al-Ihyâ', in al-Ghazâlî, Ihyâ' 'Ulûm al-Dîn (Kairo: Mushthafâ al-Bâbî al-Halabî, 1939), volume I, p. 193.

- Jalâl al-Dîn al-Suyûthî, Kitâb al-Nuqâyah, in Abû Ya'qûb alSakkaki, Iftâh al-'Ulûm (Mesir: al-Mathba 'ah al-Adabiyah, n.d.), p. 260 .

c. Articles

-.L.E. Goodman, "The Translation of Greek Materials into Arabic," in M.J.L. Young, et al. (ed.), Religion, Learning and Science in the 'Abbasid Period (Cambridge: Cambridge University Press, 1990), p. 477. 
- Barbara D. Metcalf, "Deobandis," in John L. Esposito (ed.), The Oxford Encyclopedia of the Modern Islamic World (New York: Oxford University Press, 1995), volume I, p. 362.

- Paul Edwards (ed.), The Encyclopedia of Philosophy (New York: Macmillan Publishing Co., 1967), volume III, p. 81.

- Azyumardi Azra, "Pendidikan Tinggi Islam dan Kemajuan Sains (Sebuah Pengantar)," in Charles Michael Stanton, Pendidikan Tinggi dalam Islam: Sejarah dan Peranannya dalam Kemajuan Ilmu Pengetahuan, translate Affandi and Hasan Asari (Jakarta: Logos Publishing House, 1994), p. vi.

- Taufik Abdullah, "Pengantar," in Azyumardi Azra, Renaisans Islam Asia Tenggara: Sejarah Wacana dan Kekuasaan (Bandung: Remaja Rosadakarya, 1999), p. iv.

- Ja'far, "Tarekat dan Gerakan Sosial Keagamaan Shaykh Hasan Maksum," in Teosofi: Jurnal Tasawuf dan Pemikiran Islam, Vol. 5, No. 2, 2015, p. 156.

- Anne B. Fisher, "Ford is Back on the Track," in Fortune (23 December 1985), p. 18.

-.Ja'far, "Al Washliyah Benteng Tradisi Sunni Sumut," in Waspada (1 December 2012), p. B4.

d. Researchs

- Mehdi Aminrazavi, "Suhrawardi's Theory of Knowledge" (Ph.D. Dissertation, Temple University, 1989), p. 47.

- Dja'far Siddik, et al. "Perspektif Pendidik Al Washliyah tentang Paham dan Penanggulangan Radikalisme dan Terorisme di Indonesia" (Research, Faculty of Tarbiyah and Teaching UIN Sumatera Utara, 2016). 


\section{e. Interview}

- Ramli Abdul Wahid, Al Washliyah's Council of Fatwa in Jakarta, 12 March 2013.

11. Translation guidelines:

\begin{tabular}{|c|c|c|c|c|}
\hline$=\mathrm{a}$ & $=\mathrm{kh}$ & $=$ sy & $=g h$ & $=\mathrm{n}$ \\
\hline$=b$ & $=\mathrm{d}$ & $=\mathrm{sh}$ & $=\mathrm{f}$ & $=\mathrm{w}$ \\
\hline$=\mathrm{t}$ & $=\mathrm{dz}$ & $=\mathrm{dh}$ & $=\mathrm{q}$ & $=h$ \\
\hline$=\mathrm{ts}$ & $=r$ & $=$ th & $=\mathrm{k}$ & $=\prime$ \\
\hline$=j$ & $=\mathrm{z}$ & $=\mathrm{zh}$ & $=1$ & $=$ ya \\
\hline$=\underline{\mathrm{h}}$ & $=\mathrm{s}$ & $={ }^{\prime}$ & $=\mathrm{m}$ & \\
\hline
\end{tabular}

